\title{
Erythrocyte Distribution Width and Central Corneal Thickness in Patients with Obstructive Sleep Apnea Syndrome
}

\section{Obstrüktif Uyku Apne Sendromlu Hastalarda Eritrosit Dağılım Genișliği ve Santral Kornea Kalınlığının Değerlendirilmesi}

\author{
๑ Figen Yavlal, ๑ Rahşan İnan*, (๑) Gülay Kenangil** \\ Medicana International Istanbul Hospital, Clinic of Neurology, Istanbul, Turkey \\ *University of Health Sciences Turkey, Kartal Dr. Lütfi Kırdar City Hospital, Clinic of Neurology, Istanbul, Turkey \\ **Bahçeşehir University Faculty of Medicine, Department of Neurology, Istanbul, Turkey
}

\begin{abstract}
Objective: Tissue hypoxia results in an increased erythrocyte distribution width (EDW) and secondary ocular complications in obstructive sleep apnea syndrome (OSAS). Thus, this study aimed to investigate the correlation between EDW and central corneal thickness (CCT) in patients with varying OSAS severities.

Materials and Methods: This study included 70 patients with OSAS (23 mild, 22 moderate, and 25 severe cases) and 30 healthy participants. EDW was measured using an automated blood cell counter. CCTs were measured by spectral-domain optic coherence tomography.

Results: The EDW values were significantly higher in patients with severe OSAS than with moderate $(p=0.042)$ and mild $(p=0.015)$ OSAS. Additionally, EDW values were significantly higher in the control group than in patients with mild $(p=0.011)$ and moderate OSAS $(p=0.038)$. The control group and the patient group did not significantly differ in the mean CCT values ( $p=0.45 / p=0.14)$. No statistically significant correlation was found between EDW and CCT values in the control group $(r=-0.22$, $\mathrm{p}=0.25)$ or patient group $(\mathrm{r}=-0.1, \mathrm{p}=0.63)$. The correlations between RDW and apnea-hypopnea index $(r=0.334, p=0.001)$ and minimal oxygen saturation $(r=-0.29, p=0.004)$ were statistically significant.

Conclusion: Our study revealed that EDW was higher in patients with OSAS than control group. Therefore, EDW can be used as an important diagnostic tool for the early diagnosis of atherosclerosis risk in patients with OSAS. The required metabolic activity for the sustainability of corneal transparency is thought to be affected by hypoxia in OSAS.

Keywords: Obstructive sleep apnea syndrome, erythrocyte distribution width, central corneal thickness
\end{abstract}

Öz

Amaç: Obstrüktif uyku apne sendromunda (OUAS) doku hipoksisi eritrosit dağılım genişliğinde (EDG) ve sekonder oküler komplikasyonlarda artışa neden olur. Bu çalışmada, değişik şiddetlerdeki OUAS hastalarında doku hipoksisine bağlı santral kornea kalınlıkları (SKK) ile EDG arasındaki ilişkinin değerlendirilmesi amaçlanmıştır.

Gereç ve Yöntem: Çalışmaya yaş ve cinsiyet yönünden benzer 23 hafif, 22 orta ve 25 ağır dereceli toplam 70 OUAS hastası ile eşlik eden komorbiditesi bulunmayan 30 sağlıklı birey alındı. EDG otomatik kan sayım cihazı kullanılarak, SKK ise spektral optik koherans tomografi yöntemi ile ölçüldü.

Bulgular: Ağır OUAS hastalarında EDG değerleri, orta $(p=0,042)$ ve hafif $(p=0,015)$ hastalara oranla daha yüksekti. Kontrol grubunda EDG, hafif OUAS $(p=0,011)$ ve orta OUAS $(p=0,038)$ gruplarına kıyasla istatistiksel olarak anlamlı daha yüksekken, ortalama SKK değerleri arasında anlamlı fark yoktu $(p=0,45 / p=0,14)$. Kontrol grubu $(r=-0,22 \quad p=0,25)$ ile hasta grubu $(r=-0,1 p=0,63)$ arasında EDG ve SKK değerleri arasında istatistiksel olarak anlamlı bir korelasyon yoktu. EDG'nin, apne-hipopne indeksi $(r=0,334, p=0,001)$ ve minimum oksijen satürasyonu $(r=-0,29$, $\mathrm{p}=0,004$ ) ile korelasyonu istatistiksel olarak anlamlıydı.

Sonuç: Çalışmamızda OUAS hastalarında EDG'nin kontrol grubuna göre daha yüksek olduğunu bulduk. Bu nedenle EDG, OUAS'li hastalarda ateroskleroz riskinin erken teşhisi için önemli bir tanı aracı olarak kullanılabilir ve OUAS'de hipoksi korneal saydamlık için gerekli olan metabolik aktiviteyi etkilemektedir.

Anahtar Kelimeler: Obstrüktif uyku apne sendromu, eritrosit dağılım genişliği, santral korneal kalınlık

Address for Correspondence/Yazışma Adresi: Rahşan İnan MD, University of Health Sciences Turkey, Kartal Dr. Lütfi Kırdar City Hospital, Clinic of Neurology, İstanbul, Turkey Phone: +90 5323239450 E-mail: rahinan@yahoo.com ORCID-ID: orcid.org/0000-0002-6084-055X

Received/Geliş Tarihi: 10.04.2021 Accepted/Kabul Tarihi: 27.07.2021 


\section{Introduction}

Obstructive sleep apnea syndrome (OSAS) is a disease characterised by full (apnea) or partial (hypopnea) upper respiratory tract obstruction episodes repeating during sleep, and frequently a decrease in blood oxygen saturation (1).

It is considered that OSAS is not only a respiratory disorder that involves apnea and hypopnea, but should also be taken as a disease accompanied by systemic inflammation. The desaturation and reoxygenation cycles occurring during sleep cause a reperfusion damage, giving rise to the release of proinflammatory cytokines (2). As the severity of the OSAS and the duration of hypoxia increase, so do the emerging inflammatory cytokines (3).

Episodic hypoxia episodes form the basis of the pathogenesis of ocular complications in OSAS. Ischemia-reperfusion damage, hypercoagulability, the production of free radicals, endothelial dysfunction, direct anoxic damage to the optic nerve, changes in blood pressure, and excessive sympathetic activity cause indirect optic nerve damage $(4,5)$. An interrelation between OSAS and ophthalmic pathologies such as glaucoma, keratoconus, papilledema, optic neuropathy and non-arteritic ischemic optic neuropathy has been reported in the literature $(6,7)$.

The reflection of the systemic inflammation caused by acute hypoxia to the bone marrow affects erythropoiesis, and induces an increase in serum erythropoietin (EPO), and the formation of red blood cells (RBCs). The presence of large RBCs disrupts the erythrocyte distribution width (EDW), resulting in an increase in the EDW (8).

Since EDW is sensitive to even a small amount of large RBCs, it can be used to study its relation with diseases caused not only by acute hypoxia, but also episodic or chronic hypoxia. It is known that an increase in EDW together with other inflammatory cytokines represents an increased risk factor for cardiovascular diseases $(9,10)$. EDW is considered to be the memory of chronic and serious diseases through hypoxia (11). Therefore, EDW can be used as an important diagnostic tool for the early detection of ocular complications caused by atherosclerosis and hypoxia in patients with OSAS. It has been postulated that during respiratory events in the sleep, recurrent episodes of hypoxemia and hypercapnia may increase the intracranial pressure and sympathetic activation which contribute to the development of ocular pathology (7). Knowledge of these corneal abnormalities due to sleep disturbances and hypoxemia may assist in communication between ophthalmologists and sleep specialists, thereby preventing ocular complications in patients with OSAS. This study aims at evaluating the correlation between EDW and corneal thickness caused by tissue hypoxia in patents with OSAS.

\section{Materials and Methods}

\section{Participants and study design}

One hundred patients subjected to all-night polysomnography (PSG) between January 2018-February 2019 at the Bahçeşehir University Faculty of Medicine Hospital Sleep Laboratory due to an OSAS diagnosis participated in this study after their informed consents were obtained.

One hundred subjects similar in terms of age and gender were divided into four groups according to their apnea-hypopnea index $(\mathrm{AHI})$ results. Based on their $\mathrm{AHI}$ scores, patients were categorized in control group ( $\mathrm{AHI}<5)$, mild (AHI=5-15), moderate $(\mathrm{AHI}=15-30)$, and severe OSAS (AHI>30) groups according to American Academy of Sleep Medicine (AASM) task force criteria (12).

- Thirty cases under 5: Control group,

- Twenty-three cases between 5-15: Mild OSAS group,

- Twenty-two cases between 15-30: Medium OSAS group

- Twenty-five cases above 30: Severe OSAS group.

As a control group, 30 asymptomatic healthy individuals without cardiovascular diseases who visited department of neurology outpatient clinic for check-up were enrolled in to the study.

Exclusion criteria were as follows: Impaired cardiopulmonary function, defined as the occurrence of respiratory failure, pulmonary infection or congestive heart failure; hypertension, diabetes mellitus, using antihypertensives, antidiabetics and lipid-lowering treatment; chronic alcoholism and smoking; malignancy, hyperthyroidism and hypothyroidism; history of prolonged use of non-steroid anti-inflammatory drugs or anticoagulants; renal and liver insufficiency; known hematologic disease such as leukemia or myelodysplastic syndrome; a history of recent blood transfusion; active infections, psychiatric sleep disorders, sleep respiratory dysfunctions other than OSAS (central sleep apnea or Cheyne Stokes respiratory and upper airway resistance syndrome); those having a history of eye operation, refractive laser surgery, contact lens implantation, corneal disease, ocular trauma, vasculitis, dry eye syndrome, keratoconus; use of anti-glaucoma medication, and ocular hypertension; those under 18 years of age.

\section{Polysomnographic evaluation}

The gold standard for diagnosing OSAS is PSG performed at sleep laboratories (13). An AHI of over 5 found by PSG performed on a patient with symptoms such as snoring, witnessed apnea, and excessive daytime sleepiness is considered diagnostic.

Subjects complaining of snoring and excessive daytime sleepiness were subjected to all-night PSG at our sleep laboratory, using our 48-channel device (MiniScreen, Löwenstein Medical, Germany). Electrooculogram (dual-channel), electroencephalography (6 channels, C4-M1, F4-M1, O2-M1, C3-M2, F3-M2, O1-M2), electromyogram from the submental muscle (1 channel), leg movements from the bilateral anterior tibial muscle (2 channels), electrocardiogram, airflow (oronasal thermistor and nasal cannula), body position sensor and snoring sensor records, and video monitorisation were obtained from all subjects. Arterial oxygen saturation recordings were made at chest and abdominal muscles by means of respiratory effort (2 channel) straps and pulse oximetry. All PSG records were manually scored according to the AASM criteria (14) at 30-second epochs. Apnea was scored as a minimum 10-second drop in $\geq 90 \%$ airway amplitude, and hypopnea as a 10 -second 
drop in $\geq 30 \%$ airway amplitude and $\geq 3 \%$ oxygen desaturation. $\mathrm{AHI}$ represents the number of apnea and hypopnea in 1 hour of sleep, and subjects with $\mathrm{AHI}>5$ were identified as the OSAS group, and those with $\mathrm{AHI}<5$ as the control group.

\section{Ophthalmic measurement}

After the subjects' pupils were dilated using topical procaine hydrochloride $0.5 \%$ (Alcon-Couvreur; Puurs, Belgium), their central corneal measurements were taken three times using ultrasonographic pachymeter (Opticon 2000 SPA; Pacline, Rome, Italy). In the recent years, optical coherence tomography (OCT) has stood out as an important diagnostic imaging technology especially for retinal diseases and glaucoma. This technology is capable of displaying pathologies on the retina that are hardly noticeable through fundoscopy, in highresolution images (15). In ophthalmology, OCT is used also in examining other tissues as well as for viewing the retina. It is possible to evaluate central corneal thickness (CCT) and the thickness of the cornea epithelium using anterior segment OCT (16).

\section{EDW}

After the PSG records of all subjects were taken, their EDWs were measured using an automatic blood cell count device on their blood taken in the morning. Their EDW measurements were performed using a Beckman Coulter LH-750 Hematology Analyzer (Beckman Coulter, Inc., Fullerton, CA, USA) device. The normal reference values for EDW in our laboratory are in the range of 11.6 and $16.5 \%$.

This research was approved by the Ethics Committee of the Faculty of Medicine, Bahçeşehir University (date: 03.04.2019, number: 2019-07/01) and was conducted according to principles of the Declaration of Helsinki.

\section{Statistical Analysis}

The data were analysed using the SPSS packaged software. The continuous variables were given as \pm standard deviation. The One-Way Analysis of Variance (ANOVA, post hoc: Tukey HSD for multiple comparisons) was performed for comparing independent group variances. The Spearman correlation analysis was employed for examining the correlation between variables.

\section{Results}

The demographic and clinical profile and polysomnographic parameters of the subjects are shown in Table 1.

The mean age of patients with moderate and severe OSAS was higher than that of mild OSAS and controls $(p=0.002)$. Patients with moderate and severe OSAS had higher arousal index and Epworth score $(p=<0.0001, p=0.046)$, mean oxygen saturation was found to be lower, although not statistically significant. Body mass index (BMI) increased with disease severity and it was found to be higher than the control group $(p<0.0001)$ (Table 1).

The EDW values were 12.6 \pm 0.74 in mild OSAS group, $12.75 \pm 0.77$ in moderate OSAS group and $13.5 \pm 1.67$ in severe OSAS group. The difference was significant when mild and severe OSAS groups were compared $(p=0.015)$, the moderate and severe OSAS groups' EDW results were also significantly different $(p=0.042)$ (Table 1$)$.

The EDW values of mild OSAS and control groups were significantly different $(p=0.011)$. P-value was also significant between moderate OSAS and control groups $(p=0.038)$.

Mean corneal thickness was measured as $540.92 \pm 33.7 / 543.68 \pm 29.1$ $\mu \mathrm{m}$ for the OSAS group, and as $533.83 \pm 34.43 / 529.4 \pm 43.15 \mu \mathrm{m}$ for the control group $(p=0.45 / p=0.14)$, the difference between the two groups not having been considered statistically significant as shown in Table 2.

In the patient group, the correlation between the EDW values and the $\mathrm{AHI}(r=0.334, \mathrm{p}=0.001)$, the lowest oxygen saturation $(r=-0.29, p=0.004)$ and BMI $(r=0.338, p=0.004)$ was found statistically significant (Table 3 ) (Figure 1, 2).

\section{Discussion}

In this study, we evaluated the EDW values and corneal thickness, and the relation between them, in control group and mild, medium and severe OSAS patients. In our study we found

\begin{tabular}{|c|c|c|c|c|c|}
\hline & $\begin{array}{l}\text { Control } \\
(n=30)\end{array}$ & $\begin{array}{l}\text { Mild } \\
(n=22)\end{array}$ & $\begin{array}{l}\text { Medium } \\
(n=23)\end{array}$ & $\begin{array}{l}\text { Severe } \\
(n=25)\end{array}$ & $\mathrm{p}^{*}$ \\
\hline Age (years) & $42.1 \pm 2.4$ & $46.7 \pm 13.41$ & $55.5 \pm 13.1$ & $52.16 \pm 11.5$ & 0.002 \\
\hline $\begin{array}{l}\text { Gender } \\
\text { Female } \\
\text { Male }\end{array}$ & $\begin{array}{l}18 \\
9 \\
\end{array}$ & $\begin{array}{l}4 \\
18 \\
\end{array}$ & $\begin{array}{l}6 \\
16 \\
\end{array}$ & $\begin{array}{l}9 \\
17 \\
\end{array}$ & 0.004 \\
\hline Min. $\mathrm{SpO}_{2}(\%)$ & $85.14 \pm 17.5$ & $83.74 \pm 6.3$ & $81.05 \pm 6.9$ & $66.04 \pm 13.3$ & $<0.0001$ \\
\hline Mean $\mathrm{SpO}_{2}(\%)$ & $96.10 \pm 17.8$ & $94.13 \pm 2.3$ & $93.68 \pm 1.8$ & $90.24 \pm 4.7$ & 0.531 \\
\hline Epworth scale & $6(1-22)$ & $8(1-19)$ & $6(2-15)$ & $9.5(1-21)$ & 0.046 \\
\hline BMI $\left(\mathrm{kg} / \mathrm{m}^{2}\right)$ & $26.46 \pm 5.71$ & $28.87 \pm 3.05$ & $28.36 \pm 3.86$ & $33.36 \pm 6.86$ & $<0.0001$ \\
\hline
\end{tabular}


that the EDW was greater in OSAS patients compared to the control group. Also, the EDW values of severe OSAS patients were statistically higher compared to those of mild and medium OSAS patient groups. However, patient and control groups did not show a significant difference with regard to corneal thickness.

The fact that the mean age of patients with moderate and severe OSAS was higher than that of mild OSAS and controls is due to the increase in disease severity with age. Increase in aurosal index, decrease in mean oxygen saturation and increase in Epworth score also resulted as expected in severe and moderate OSAS patients. Since BMI increases with disease severity, it was found to be higher in OSAS group than the control group which was in line with previous studies $(17,18)$.

The desaturation and reoxygenation cycles emerging during sleep causes reperfusion damage. Pro-inflammatory cytokines are released as a result of developing hypoxia and sympathetic discharge $(2,3)$. The reflection of systemic inflammation to the bone marrow causes EPO activation, giving rise to erythrocyte heterogeneity, which, in turn, results in an increase in EDW (3). In our study, while an increase was found also in the EDW's values of medium and severe OSAS patients with a high AHI, an inverse proportion was found with minimum oxygen saturation. Similar studies carried out in the past also support our findings. EDW may not be an ideal indicator for hypoxia. EDW's potential of being sensitive to hypoxic events does denote high specificity. EDW increase is also present in acute bowel diseases, anaemia and goitre. EDW is also expected to increase in methotrexate, the use of nucleoside transcriptase inhibitors, and alcohol poisoning.

The onset of a hypoxic disease contributes to the patient's pre-existing hypoxic load. Therefore, a patient with cardiac insufficiency and chronic obstructive pulmonary disease will be less defensive against hypoxemia secondary to pneumonia. Since EDW is a sensitive indicator of hypoxic load, it may provide information on morbidity and mortality (19-22).

\begin{tabular}{|l|l|l|l|}
\hline \multicolumn{4}{|l|}{ Table 2. Corneal thickness in the participants } \\
\hline Corneal thickness & Control & OSAS & $\mathbf{p}$ \\
\hline Right & $533.83 \pm 34.43$ & $540.92 \pm 33.7$ & 0.45 \\
\hline Left & $529.4 \pm 43.15$ & $543.68 \pm 29.1$ & 0.14 \\
\hline \multicolumn{4}{|l}{} \\
\hline
\end{tabular}

Table 3. Correlation of the EDW values and the polysomnographic and clinical parameters

\begin{tabular}{|l|l|l|}
\hline & \multicolumn{2}{|l|}{ EDW values } \\
\cline { 2 - 3 } & $\mathbf{r}^{*}$ & $\mathbf{p}$ \\
\hline AHI & 0.334 & $<\mathbf{0 . 0 0 0 1}$ \\
\hline Min. $\mathrm{SpO}_{2}$ (\%) & -0.29 & $\mathbf{0 . 0 0 4}$ \\
\hline BMI & 0.338 & $<\mathbf{0 . 0 0 0 1}$ \\
\hline RERA & -0.13 & 0.11 \\
\hline $\begin{array}{l}\text { *Pearson correlation constant, AHI: Apnea-hypopnea index, BMI: Body mass } \\
\text { index, EDW: Erythrocyte distribution width, Min. SpO } \\
\text { saturation : Lowest oxygen }\end{array}$ \\
\hline
\end{tabular}

In ophthalmology, the measurement of CCT is clinically very important for the preoperative evaluation of patients prior to refractive surgery $(23,24)$. Ophthalmologists currently use ultrasound pachymetry (UP) to measure corneal thickness. The advantages of UP are its accessibility and portability, and it may also be used for evaluating normal corneas (25).

Being a transparent tissue, the cornea is one of the most important steps of the optic function. Oxygen is an important parameter for the metabolic activity ensuring the continuation of cornea transparency. Anaerobic glycosis increasing due to hypoxia causes stromal oedema in the cornea. Long-lasting stromal oedema causes changes in keratocyte morphology and functions. Studies have demonstrated that an approximately $2 \%$ thinning occurs in the cornea even after the disappearance

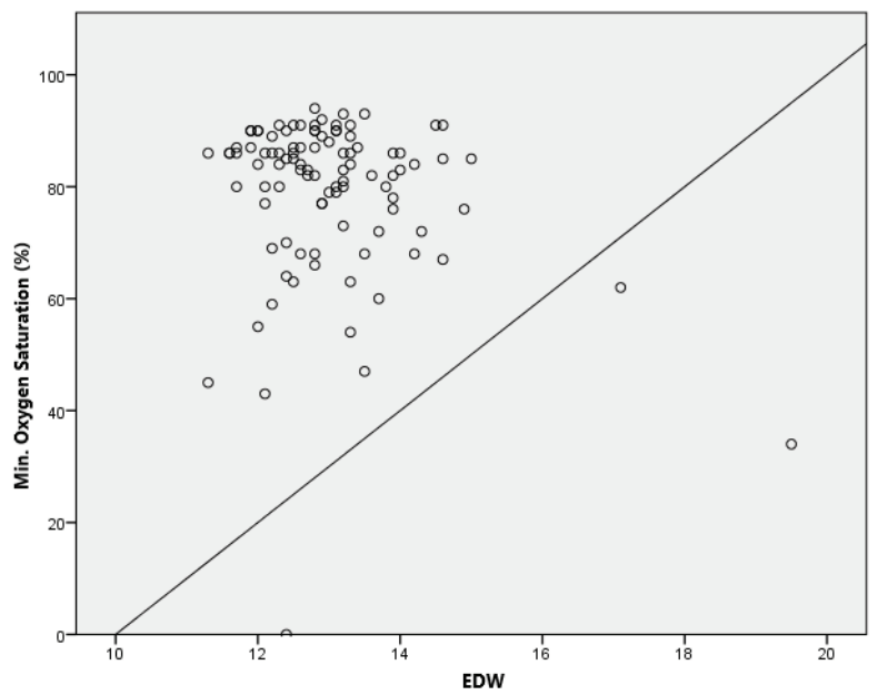

Figure 1. Correlation between the EDW values and the lowest oxygen saturation

EDW: Erythrocyte distribution width

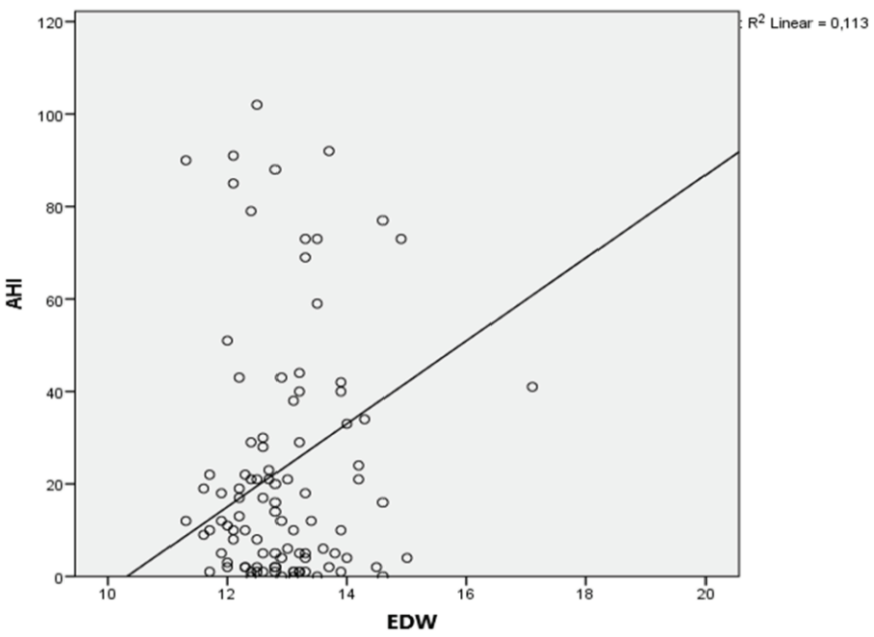

Figure 2. Correlation between the EDW values and apneahypopnea index

EDW: Erythrocyte distribution width 
of the corneal oedema $(26,27)$. Akbulut et al. (28), in a study in which they researched OSAS patients' proclivity to glaucoma, found no distinct thinning in the measured corneal thicknesses of OSAS patients. Koseoglu et al. (29) reported that corneal thicknesses decreased in the OSAS group compared to the control group. It was found that CCT decreases as OSAS severity increases. Our study, however, found no significant difference between the OSAS groups and the control group in terms of corneal thickness. The reason for this may be the smaller number of the patients participating in our study. Therefore, studies with greater numbers of patients in which the systemic effects in OSAS and the impact of tissue hypoxia on the cornea are evaluated would be useful.

In several studies, optic nerve damage caused by hypoxia has also been demonstrated in OSAS in addition to corneal thinning (30). Purvin et al. (31) suggested that OSAS may cause papilledema and visual impairment due to an increase in intracranial pressure caused by episodic nocturnal hypoxemia. Karakucuk et al. (32) demonstrated field of vision defects secondary to optic nerve damage caused by cerebral ischemia in OSAS patients in spite of normal ophthalmological examination. Acute bleeding provoking EPO-guided erythropoiesis is followed by increases in RDW, but not mean cell volume. Similar increases in RDW are followed by many acute diseases with a risk of hypoxia, including cardiac insufficiency, pneumonia, atelectasis, pulmonary embolism, pneumothorax, and sepsis. The peaks reach maximum within 1 month following onset, and drop to pre-disease levels approximately 6 months later. In contrast to iron deficiency anaemia (IDA), no noticeable change in the average RBC dimension accompanies RDW increases following diseases related to hypoxia.

While statistically insignificant, it is believed that the metabolic activity required for maintaining corneal transparency is affected by the hypoxia caused by OSAS. In OSAS, the pathogenesis of ocular complications has a multifactor origin with ischemiareperfusion damage, hypercoagulability, the production of free radicals, and increased oxidation. Indirect optic nerve damage emerges secondary to stress, endothelium dysfunction, direct anoxic damage to the optic nerve, changes in blood pressure, and sympathetic excess activity.

\section{Study Limitations}

The limitations of our study were the lack of knowledge on the time of the onset of OSAS symptoms and systemic effect, the small number of participants, and the BMI difference between the groups. Excluding individuals with known diseases other than OSAS suggests that the obtained results developed in connection with OSAS' systemic effects.

\section{Conclusion}

The results of this study revealed that patients with OSAS have higher EDW values. EDW showed a positive correlation with $\mathrm{AHI}$ but an inverse correlation with the lowest oxygen saturation. Therefore, EDW might be used as a severity marker of OSAS and it could provide an inexpensive and easy tool for evaluating OSAS patients in terms of potential tissue hypoxia- associated diseases. Prospective studies with larger populations are needed to confirm EDW and CCT as a useful severity assessment tool in OSAS.

\section{Ethics}

Ethics Committee Approval: This research was approved by the Ethics Committee of the Faculty of Medicine, Bahçeşehir University (date: 03.04.2019, number: 2019-07/01) and was conducted according to principles of the Declaration of Helsinki. Informed Consent: Informed consent was obtained. Peer-review: Externally and internally peer-reviewed.

\section{Authorship Contributions}

Concept: F.Y., R.I.,, G.K., Design: F.Y., R.I., G.K., Data Collection or Processing: F.Y., R.I., G.K., Analysis or Interpretation: F.Y., R.I.., G.K., Literature Search: F.Y., R.I., G.K., Writing: F.Y., R.İ., G.K.

Conflict of Interest: No conflict of interest was declared by the authors.

Financial Disclosure: The authors declared that this study received no financial support.

\section{References}

1. International Classification of Sleep Disorders Published online 4 ed. IL: American Academy of Sleep Medicine, Darien, 2014,53-62.

2. Williams A, Scharf SM. Obstructive sleep apnea, cardiovascular disease, and inflammation is NF-kappaB the key? Sleep Breath 2007; 11:69-76.

3. Jelic S, Padeletti M, Kawut SM, Higgins C, Canfield SM, Onat D, Colombo PC, Basner RC, Factor P, Lejemtel TH. Inflammation, oxidative stress, and repair capacity of the vascular endothelium in obstructive sleep apnea. Circulation 2008;117:2270-8.

4. Lopez-Jimenez F, Sert Kuniyoshi FH, Gami A, Somers VK. Obstructive sleep apnea. Chest 2008;133:793-804.

5. Grover DP. Obstructive sleep apnea and ocular disorders. Curr Opin Ophthalmol 2010; 21:454-8.

6. McNab AA. The eye and sleep apnea. Sleep Med Rev 2007;11:269-76.

7. Fraser CL. Obstructive sleep apnea and optic neuropathy: is there a link? Curr Neurol Neurosci Rep 2014;14:465.

8. Weiss G, Goodnough LT. Anemia of chronic disease. N Engl J Med 2005;352:1011-2.

9. Libby P, Ridker PM, Maseri A. Inflamation and aterosclerosis. Circulation 2002;105:1135-43.

10. Dabbah S, Hammerman H, Markiewicz W, Aronson D. Relation between red cell distribution width and clinical outcomes after acute myocardial infarction. Am J Cardiol 2010;105:312-7.

11. Yčas JW, Horrow JC, Horne BD. Persistent increase in red cell size distribution width after acute diseases: A biomarker of hypoxemia? Clin Chim Acta 2015;448:107-17.

12. No authors listed. Sleep-related breathing disorders in adults: recommendations for syndrome definition and measurement techniques in clinical research. The report of an American Academy of Sleep Medicine Task Force. Sleep 1999;22:667-89.

13. Guilleminault C. Clinical features and evaluation of obstructive sleep apnea. In: Karger MH, Roth T, Dement WC, eds. Principles and practice of sleep medicine. Sauders, London, 1994:165-70.

14. Iber C, Ancoli-Israel S, Chesson AL, Quan SF, American Academy of Sleep Medicine. The AASM manual for the scoring of sleep and associated events: rules, terminology and technical specifications, 1 st ed. Westchester, IL: American Academy of Sleep Medicine; 2000. 
15. Mumcuoğlu T, Erdurman FC, Durukan AH. Principles and novel clinical applications of optical coherence tomography. Turk J Ophthalmol 2008;38:168-75.

16. Yıldız Y, Gürdal C, Saraç O, Aşık Nacaroğlu Ş, Takmaz T, Can I. The Long-Term Effects of Silicone Hydrogel Contact Lens Wear on Corneal Morphology. Turk J Ophthalmol 2012;42:91-6.

17. Young T, Skatrud J, Peppard PE. Risk factors for obstructive sleep apnea in adults. JAMA 2004;291:2013-6.

18. Schäfer H, Pauleit D, Sudhop T, Gouni-Berthold I, Ewig S, Berthold HK. Body fat distribution, serum leptin, and cardiovascular risk factors in men with obstructive sleep apnea. Chest 2002;122:829-39.

19. Ozsu S, Abul Y, Gulsoy A, Bulbul Y, Yaman S, Ozlu T. Red cell distribution width in patients with obstructive sleep apnea syndrome. Lung 2012;190:319-26.

20. Fava C, Montagnana M, Favaloro EJ, Guidi GC, Lippi G. Obstructive sleep apnea syndrome and cardiovascular diseases. Semin Thromb Hemost 2011;37:280-97.

21. Ryan S, Taylor CT, McNicholas WT. Systemic inflammation: a key factor in the pathogenesis of cardiovascular complications in obstructive sleep apnoea syndrome? Thorax 2009;64:631-6.

22. Shen CX, Tan M, Song XL, Xie SS, Zhang GL, Wang CH. Evaluation of the predictive value of red blood cell distribution width for onset of cerebral infarction in the patients with obstructive sleep apnea hypopnea syndrome. Medicine (Baltimore) 2017;96:e7320.

23. Carbonaro F, Hysi PG, Fahy SJ, Nag A, Hammond CJ. Optic disC planimetry, corneal hysteresis, central corneal thickness, and intraocular pressure as risk factors for glaucoma. Am J Ophthalmol 2014; 157:441-6.
24. Yo C, Ariyasu RG. Racial differences in central corneal thickness and refraction among refractive surgery candidates. J Refract Surg 2005;21:194-7.

25. Miglior S, Albe E, Guareschi M, Mandelli G, Gomarasca S, Orzalesi N. Intraobserver and interobserver reproducibility in the evaluation of ultrasonic pachymetry measurements of central corneal thickness. $\mathrm{Br}$ J Ophthalmol 2004;88:174-7.

26. Yeter V, Sönmez B, Beden U. Comparison of central corneal thickness measurements by Galilei Dual-Scheimpflug analyzer and ultrasound pachymeter in myopic eyes. Ophthalmic Surg Lasers Imaging 2012;43:128-34.

27. McCanna DJ, Driot JY, Hartsook R, Ward KW. Rabbit models of contact lens--associated corneal hypoxia: a review of the literature. Eye Contact Lens 2008;34:160-5.

28. Akbulut M, Arıcı MK, Doğan ÖT, Atalar MH, Erdoğan H, Toker I, Özeç Vural A. Obstrüktif Uyku Apne Sendromlu Olgularda Glokom Yatkınlığı. Glo-Kat 2007;2:13-7.

29. Koseoglu HI, Kanbay A, Ortak H, Karadağ R, Demir O, Demir S, Gunes A, Doruk S. Effect of obstructive sleep apnea syndrome on corneal thickness. Int Ophthalmol 2016;36:327-33.

30. Quigley HA, Addicks EM. Regional differences in the structure of the lamina cribrosa and their relation to glaucomatous optic nerve damage. Arch Ophthalmol 1981;99:137-43.

31. Purvin VA, Kawasaki A, Yee RD. Papilledema and obstructive sleep apnea syndrome. Arch Ophthalmol 2000;118:1626-30.

32. Karakucuk S, Goktas S, Aksu M, Erdogan N, Demirci S, Oner A, Arda $\mathrm{H}$, Gumus K. Ocular blood flow in patients with obstructive sleep apnea syndrome (OSAS). Graefes Arch Clin Exp Ophthalmol 2008; 246:129-34. 